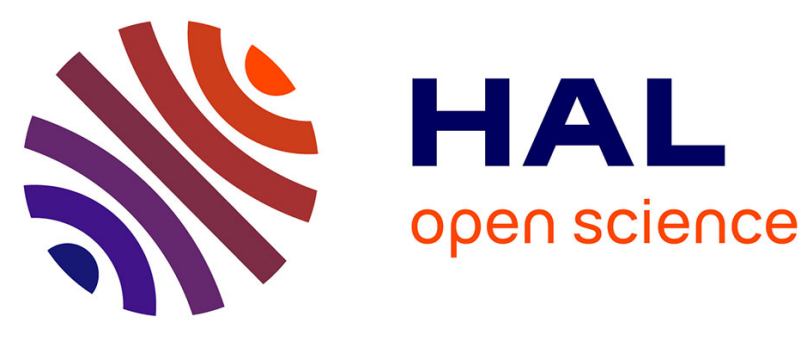

\title{
Effects of earthworms on soil organic matter and nutrient dynamics at a landscape scale over decades
}

Patrick Lavelle, Fabienne Charpentier, Cécile Villenave, Jean-Pierre Rossi, Laurent Derouard, Beto Pashanasi, Jean André, Jean-François Ponge, Nicolas Bernier

\section{To cite this version:}

Patrick Lavelle, Fabienne Charpentier, Cécile Villenave, Jean-Pierre Rossi, Laurent Derouard, et al.. Effects of earthworms on soil organic matter and nutrient dynamics at a landscape scale over decades. Edwards, C.A. Earthworm ecology, 2nd edition, CRC Press, Boca Raton, Florida, pp.145-160, 2004, 10.1201/9781420039719.pt4 . hal-00497245

\section{HAL Id: hal-00497245 \\ https://hal.science/hal-00497245}

Submitted on 16 Aug 2010

HAL is a multi-disciplinary open access archive for the deposit and dissemination of scientific research documents, whether they are published or not. The documents may come from teaching and research institutions in France or abroad, or from public or private research centers.
L'archive ouverte pluridisciplinaire HAL, est destinée au dépôt et à la diffusion de documents scientifiques de niveau recherche, publiés ou non, émanant des établissements d'enseignement et de recherche français ou étrangers, des laboratoires publics ou privés. 


\title{
Effects of Earthworms on Soil Organic Matter and Nutrient Dynamics at a Landscape Scale over Decades
}

\author{
Patrick Lavelle, ${ }^{1}$ Fabienne Charpentier, ${ }^{1}$ Cécile Villenave, ${ }^{1}$ Jean-Pierre Rossi, ${ }^{1}$ Laurent Derouard, ${ }^{1}$ Beto \\ Pashanasi, ${ }^{2}$ Jean André, ${ }^{3}$ Jean-François Ponge, ${ }^{4}$ and Nicolas Bernier ${ }^{4}$ \\ ${ }^{1}$ Laboratoire d'Ecologie des Sols Tropicaux, Bondy Cedex, France; \\ ${ }^{2}$ Estacion Experimental San Ramon, INIAA, Yurimaguas, Loreto, Peru; \\ ${ }^{3}$ Université de Savoie, France; \\ ${ }^{4} \mathrm{MNHN}$, Brunoy, France
}

After several decades of unquestioned success, agriculture is now facing important global problems. Huge increases in productivity in developed countries have been accompanied by a severe depletion of "soil quality" in terms of resistance to erosion, organic contents, concentrations of heavy metals, and pesticide residues. Agricultural intensification in developing countries has been less successful because of various socioeconomic limitations. Nevertheless, traditional agricultural practices do not conserve the quality of soils; stocks of organic matter are rapidly becoming depleted, and erosion removes fine particles from the soil surface horizons. In a context of increasing human population pressures, particularly in developing countries, this degradation of soils results in many social and environmental problems (Eswaran 1994; FAO 2000). Features common to all kinds of soil degradation are a significant decrease in organic reserves, degradation of the soil structure, and severe depletion of soil invertebrate communities, especially earthworms (Decaëns et al. 1994; Lavelle et al. 1994).

The contributions of earthworms to soil fertility have been described in several hundreds articles and books (Lee 1985; Edwards and Bohlen 1996; Lavelle and Spain 2001). This has led to a growing expectation from soil users for provision of methods that protect soil fertility through the enhancement of biological processes. Earthworms may be considered a biological resource for farming systems, and the management of earthworm communities provides a promising field for innovation in agricultural practices (Lavelle et al. 1999). Demand for techniques, making use of earthworms as a resource, is likely to increase, although basic research is still needed to support such developments. 
The relationships between earthworm activities and changes in soil properties are not thoroughly understood, especially at large timescales of years to decades. Most research results have been obtained in smallscale laboratory or field experiments that exaggerate the process under study and can by no means be extrapolated readily to larger scales of time and space. However, recent research on earthworm casts and other related biogenic structures have shown that these structures persist for rather long periods and provide the soil with specific properties that may survive the death and elimination of earthworm populations that produced them. This property contributes significantly to the resistance and resilience of soils to disturbances (Lavelle et aL 2004).

This chapter synthesizes information on the effects of earthworms on soil systems at scales longer than 1 year, and earthworm behavior that may affect these processes is detailed.

\section{EARTHWORMS AND SOIL FUNCTION: THE DRILOSPHERE CONCEPT}

For example, at a real scale of a smal1 tropical farmer's plot, earthworm activities are only one determinant of soil fertility, and their effects are likely determined by factors operating at larger scales of time and space, such as climate, edaphic characteristics, and the quality and amount of organic inputs (Lavelle et al. 1993). Earthworms participate in soil functions through the drilosphere system, which involves earthworms, casts, and burrows and the whole microbial and invertebrate community that inhabits these structures. As a result of earthworm digestion processes and creation of soil structures, the composition, structure, and relative importance of the drilosphere system to soils is clearly determined by climate, soil parameters, and the quality of organic inputs. Earthworms in turn influence soil microbial communities and hence have effects on microbial processes related to soil organic matter (SOM) status and nutrient dynamics. They also affect the activities of soilinhabiting invertebrates, either by modifying their environment or through competition for feeding resources (Figure 8.1).

Earthworms are not a homogeneous entity. They comprise several functional groups, each with clearly distinct ecology and impacts on the environment (Bouché 1977). Current classifications based on earthworm location in the soil profile and their feeding resources are still too general to describe the large diversity in functions. Moreover, earthworms classified into a general category may not always exhibit the behavioral traits 
expected to be associated to this category (Neilson et al. 2000; Mariani et al. 2001). Classifications based more on impacts on soil parameters might be more useful.

The effects of earthworms on soil function thus depend on their interactions with a wide range of identified abiotic and biotic factors that operate at rather different scales of time and space. Furthermore, the effects produced will affect soil structures of different sizes and persist for highly variable periods of time, depending on the factors with which they interact. For example, it is expected that physical structures created by earthworms as a result of their interactions with other soil components will last much longer than the flush of activity of dormant microorganisms that they have activated in their guts (Figure 8.2).

Most studies have described processes at smaller scales of earthworm activities, typically in microcosms, small plots or small field enclosures. Results obtained under such conditions describe existing processes but cannot be extrapolated directly to quantify and predict effects produced at the scale at which SOM dynamics and nutrient cycling are generally studied. One spectacular result of this smaller-scale approach is a huge discrepancy between the great importance that pedobiologists attribute to earthworms as regulators of soil physical structure and SOM dynamics and the absence of any representation of earthworm activities in simulation models that describe SOM dynamics at scales of decades and hectares (Jenkinson and Rayner 1977; Molina et al. 1983; Parton et al. 1988; Agren et al. 1991). A few papers have already described the effects of earthworms at the scales of the different biotic and abiotic parameters with which they interact, such as (1) selection of ingested particles and digestion processes at the scale of a gut transit ( 0.5 to 20 hours) (Lee 1985; Barois and Lavelle 1986); (2) immobilization-reorganization of nutrients in fresh casts (1 to 20 days) (Syers et al. 1979; Lavelle et al. 1992; Lopez-Hernandez et al. 1993; Tiunov et al. 2001); and (3) evolution of SOM in aging casts (3 to 30 months) (Martin 1991; Lavelle and Martin 1992; Blair et al. 1994; McInerney et al. 2000). Long-term evolution of SOM at the scale of the whole soil profile and pedogenesis during periods of years to centuries has been identified, although little information is currently available (Figure 8.3).

This chapter describes the effects of earthworms on larger-scale SOM and nutrient dynamics observed in 3-year field experiments and details three subprocesses that may determine the long-term effects of earthworms on soils: feeding behaviors, patterns of horizontal distribution, and participation of earthworm activities in successional processes. Simulations of SOM dynamics, based on the CENTURY model (Parton et al. 1988), give some insight on effects of earthworms on soils observed at a timescale of 10 to 50 years. 


\section{EARTHWORM BEHAVIOR}

Earthworm behavior may affect soil functions significantly. A major difference between short-scale experiments and the real world is that, in confined small experiments, earthworms have limited opportunities to choose their food and move away. This probably explains why they often lose weight or die in laboratory experiments. On the other hand, the introduction of unrealistically high earthworm populations to small enclosures in the field often creates concentrations of intense earthworm activity that would not normally have occurred in the field or that concern only microsites that are either highly dispersed in nature or infrequently visited.

\section{SELECTION OF SOIL PaRTicles}

Earthworms are known to select the organic and mineral soil components that they ingest. As a result, their casts often have much higher contents of SOM and nutrients than the surrounding soil (Lee 1985). This is probably because of preferential ingestion of plant residues (leaf and root litter debris and occasionally fungi) (Piearce 1978; Ferrière 1980; Kanyonyo ka Kajondo 1984; Bonkowski et al. 2000; Neilson et al. 2000), fecal pellets of other invertebrates (Mariani et al. 2001), and clay minerals. Barois and Lavelle (1986) demonstrated that the tropical peregrine species Pontoscolex corethrurus was able to select either large organic debris or small mineral particles, depending on soil type. Selection was made on aggregates rather than primary particles. However, some earthworms may selectively ingest coarser particles than the average in soils with very high clay contents. There is evidence that some endogeic species of earthworms ingest only aggregates that do not exceed the diameter of their mouths, whereas other species may feed on larger aggregates and split them into smaller aggregates (Derouard et al. 1997; Blanchart et al. 1999). The feeding behavior that allows such a selection has never been described in detail. The long-term consequences of that behavior on the dynamics of soil processes and SOM dynamics have not been addressed directly. Endogeic species of earthworms may deposit 20 to $200 \mathrm{t}$

dry soil $\mathrm{ha}^{-1}$ surface casts that contain a significant proportion of SOM yearly. A much larger quantity of casts is deposited inside the soil, and a volume of soil equivalent to the whole soil of the upper horizons may be passed through earthworm guts in a few years (Darwin 1881; Lavelle 1978). Nevertheless, the higher concentration of fine particles in casts than in the surrounding bulk soil suggests that earthworms may possibly reingest the same soil several times, whereas microsites with a relatively coarser texture may be avoided by earthworms. 


\section{SPatial Patterns of Horizontal Distribution Of EARThWORMS}

Several authors have pointed out the aggregated distribution of earthworm populations that occur in such diverse ecosystems as an arable soil from Germany (Poier and Richter 1992), a deciduous forest of England (Phillipson et al. 1976), humid African (Lavelle 1978) and Colombian savannahs (Decaëns and Rossi 2001; Jimenez et al. 2001), and an artificial pasture in southern Martinique (Rossi et al. 1997). In some places, the earthworm distribution was independent of basic soil parameters such as depth or clay or carbon contents. Furthermore, different earthworm species tended to have different horizontal distributions (Poier and Richter 1992); in an almost monospecific earthworm community of Polypheretima elongata in Martinique, Rossi (1997) observed different distribution patterns for adults and juvenile earthworms. These observations suggest that some earthworm species have patchy population distributions with an average patch diameter of 20 to $40 \mathrm{~m}$. Such patches seem to be independent of soil parameters, at least to some extent. The dynamics of earthworm populations in such a patch are not synchronized with the populations of other patches. The occurrence of such distribution patterns suggests that earthworm activities concentrate on patches probably only for limited periods of time before becoming locally extinct. In the moist savanna at Lamto (Côte d'Ivoire), complementary patterns have been observed between large earthworm species that produce large casts and tend to compact the soil and smaller species that produce fine granular casts after ingesting the larger casts of the first type of species with root litter (Blanchart et al. 1999). In that case, the observed patterns suggest a succession of patches made of “compacting" and "decompacting" species with complementary effects on soils.

\section{COMPACTING vS. DECOMPACTING SPECIES}

The physical structure of earthworm casts is very relevant to the dynamics of SOM at intermediate scales of months to years. Two different types of casts may be distinguished in this respect: the globular casts of compacting species and the granular casts of decompacting species. Casts of the first category may be surrounded by a thin 10 - to 20 -m $\mu$ cortex made of clay minerals and organic particles, which seem to reduce aeration and hence inhibit microbial activity at the scale of weeks to months (Martin 1991; Blanchart et al. 1993). Soils colonized by monospecific communities of such earthworm species are prone to compaction.

In an experiment in which the earthworm Millsonia anomala had been introduced into soils under a yam and a maize culture, the proportion of large aggregates bigger than $2 \mathrm{~mm}$ increased significantly in soils that 
had been sieved previously, but no significant effect was observed in a soil that had kept its original structure (Table 8.1). Soil bulk density increased significantly in both situations.

Similar effects have been observed after inoculation of the peregrine, pantropical, endogeic species $P$ corethrurus into soils under a traditional cropping system of Peruvian Amazonia. After six successive crops, earthworms had increased the proportion of macroaggregates (>2 mm) significantly from 25.4 to $31.2 \%$ at the expense of smaller $(<0.5 \mathrm{~mm})$ aggregates with proportions that had decreased from 35.4 to $27.4 \%$. Such changes in soil aggregation resulted in a slight increase of bulk density (significant during the first three cropping cycles) and a significant decrease in infiltration rates and sorptivity, the latter decreasing from $0.34 \mathrm{~cm} \mathrm{sec}^{-1}$ in nonearthworm-inoculated soils to $0.15 \mathrm{~cm} \mathrm{sec}^{-1 / 2}$ in treatments inoculated with $36 \mathrm{~g} \mathrm{~m}^{-2}$ fresh biomass of earthworms (Alegre et al. 1996). This transformation in soil physical properties resulted in eventual changes in the soil water regime because soil tended to become drier during dry periods and wetter in periods of heavy rainfall than in the non-earthworm-inoculated treatment.

Other endogeic earthworm species have been reported to have opposite effects because they tend to break down large (>0.5 mm) aggregates and split them into smaller ones (Derouard et al. 1997; Blanchart et al. 1999). For example, in western African savannahs, small species of the Eudrilidae family possess such abilities, and it has been hypothesized that soil aggregation is regulated by the opposite effects of large compacting species such as Millsonia anomala and decompacting species like the common eudrilid Hyperiodrilus africanus. In the absence of decompacting earthworms or other earthworm species, the activity of compacting earthworms may create severe soil problems. This was the case in a pasture derived from primary forest near Manaus (Brazil). At this site, the peregrine earthworm P. corethrurus had increased to rather large and active populations; at the same time, deforestation had eliminated $75 \%$ of other macroinvertebrate species, especially from the decompacting group. The accumulation of casts of $P$. corethrurus at the soil surface in very moist soil conditions resulted in the formation of a continuous muddy layer of earthworm casts. When droughts occurred, this layer turned into a compact 3 -cm thick crust that prevented plants from growing, leaving large patches of bare soil.

These results contrast with a rather broad set of other results suggesting that earthworm activities improve the aeration of soil and infiltration of water (Lee 1985; Edwards and Bohlen 1996), and P. corethrurus has been reported to repair a compacted oxisol, showing that interactions with other invertebrates and soil 
characteristics may be the ultimate determinants of the effects of earthworms on soils (Zund et al. 1997). Three hypotheses may explain such discrepancies:

1. Most studies on the relationships between earthworm activities and soil physical parameters have been based on Lumbricidae. This family, unlike most tropical families, comprises a large proportion of species that create semipermanent burrows that influence water infiltration significantly.

2. In natural ecosystems, the association of compacting and decompacting earthworm species may regulate soil physical properties and, in the end, favor infiltration and aeration. It is important to consider that decompacting species may belong to other taxa such as Enchytraeidae (Didden 1990; Van Vliet et al. 1993), ants (Decaëns et al. 2001), termites (Isoptera), or millipedes (Diplopoda) (Tajovsky et al. 1991).

3. The effects of Lumbricidae could be a consequence of the burial of large organic particles mixed with ingested soil, because it is commonly recognized that the incorporation of litter into soil has significant effects on soil physical parameters (Springett 1983; Aina 1984; Oades 1984; Kladivko et al. 1986; Shaw and Pawluk 1986; Joschko et al. 1989; Kooistra 1991; Wolters 1991).

\section{MEDIUM-TERM EFFECTS: EXPERIMENTS INOCULATING EARTHWORMS INTO CROPPING S.YSTEMS OF THE HUMID TROPICS}

Three-year experiments have been conducted at two tropical sites, Lamto (Côte d'Ivoire) and Yurimaguas (Peru). Annual cropping systems were inoculated with populations of endogeic species of earthworms, and the dynamics of the system were compared with those of noninoculated systems for six successive crops over 3 years (Pashanasi et al. 1996; Gilot 1997).

At Yurimaguas, the $\mathrm{C}$ and $\mathrm{N}$ contents of soil decreased significantly with time. After six cropping cycles, the $\mathrm{C}$ contents had decreased from 16.8 to 1.36 and $1.51 \mathrm{mg} \mathrm{g}^{-1}$ in systems inoculated with earthworms and in the control, respectively (Figure 8.4). Although systems inoculated with earthworms tended to have less C after the fourth cropping cycle, the observed differences were not significant at the end of the experiment. Changes in $\mathrm{N}$ content during the experiment showed similar trends: $\mathrm{N}$ concentrations increased initially in both systems as a result of $\mathrm{N}$ outputs after burning and incorporation of ashes in the soil. During the first three 
cropping cycles, $\mathrm{N}$ contents were higher in the earthworm-inoculated systems. From the fourth harvest, the $\mathrm{N}$ contents were lower in the earthworm-inoculated treatments, but differences were not significant. Earthworms did not affect soil nutrient contents for the first five cropping cycles: $\mathrm{Ca}, \mathrm{Mg}, \mathrm{K}$, and $\mathrm{P}$ contents increased first after burning and incorporation of ashes and thereafter decreased steadily. By the last harvest, cation contents were slightly higher in the earthworm-inoculated systems, but the differences were significant only for $\mathrm{K}$ contents. Similar trends were observed for $\mathrm{pH}$ and $\mathrm{Al}$ saturation.

At Lamto, similar results were obtained. After four cropping cycles of maize, the $\mathrm{C}$ contents in the upper $10 \mathrm{~cm}$ of soil decreased from $13.37 \mathrm{mg} \mathrm{g}^{-1}$ at time 0 to 9.75 and $9.64 \mathrm{mg} / \mathrm{g}$ in the control and earthworminoculated systems, respectively, with the differences observed between the last two treatments insignificant. In spite of these results, some differences in the quality of organic matter seemed to exist. Physical fractionation of SOM using the Feller (1979) method showed some evidence of protection of the coarse organic particles in the inoculated systems (Gilot 1997). Furthermore, laboratory respirometric tests showed a significant increase in soil respiration rates where earthworms had been active (Tsakala 1994).

Experiments by Gilot (1997) showed that the effects of earthworms in protecting coarse organic fractions were significant only in soils that had been sieved previously. In this case, reaggregation of soil by earthworms had positive effects on SOM protection. In soils that had not been sieved, large aggregates, resulting from earthworm activities in the natural soil, were conserved in the no earthworm treatment conditions during the 3 years that the experiment lasted. Thus, the effects of protection linked to aggregation were retained, although no earthworms were present.

\section{LONG-TERM EFFECTS OF EARTHWORMS: MODELING AND OBSERVATION OF SUCCESSIONAL PROCESSES}

In the absence of long-term experiments, evidence for effects of earthworms at scales from 10 to 100 years or more has been sought from simulation modeling and the observation of time sequences in successional processes.

\section{Modeling}


Currently available models that describe SOM dynamics do not take into account explicitly the effects of soil invertebrates. Part of the effects of soil-inhabiting invertebrates may be implicit, either when describing initial sail conditions (e.g., through how the C:N ratio is influenced by their activities) or when assessing the decomposition rates of $\mathrm{C}$ pools that will actually include the overall effects of earthworms. An attempt was made to simulate the effects of earthworm activities on the three kinetically defined organic pools of the CENTURY model (Parton et al. 1988). This model, which simulates plant production and SOM dynamics in various agricultural and natural systems, considers three different SOM functional pools. A labile fraction (active SOM) has a rapid turnover and exists in the form of live microbes and microbial products. The remaining fractions comprise SOM that is stabilized, either because it is physically protected (slow pool), because it is chemically resistant (passive pool) to decomposition, or both.

As a first step, the CENTURY model was used to simulate SOM dynamics and plant production in the savannah of Lamto (Martin and Parton unpublished data) and validated against observed data values. Then, the model was calibrated for this site and simulated $\mathrm{C}$ dynamics in earthworm casts and a control soil of the same savannah sieved at 2-mm aperture. Observations by Martin (1991) during a 450-day incubation of earthworm casts and a control surrounding sail sieved at $2-\mathrm{mm}$ aperture were used as a reference. For the sieved soil, the model outputs were close to the experimental results, provided slow soil $\mathrm{C}$ decomposition rates increased. Conversely, it was necessary to decrease the rates for both slow and active decomposition rates of soil $\mathrm{C}$ to simulate its dynamics in casts. Earthworm removal was simulated by replacing the active and slow soil C decomposition rates of the model with those obtained by calibration with the control soil. Under these assumptions, the CENTURY model indicated that SOM would decrease by about $10 \%$ in 30 years, the largest proportion lost in the slow pool that includes physically protected organic matter (Figure 8.5).

This suggests that slow decomposition rates of soil C may be influenced significantly by earthworm activities. This pool would comprise organic matter that binds microaggregates into macroaggregates (Elliott 1986), which is generally lost during cultivations. Earthworms may play an important role in stabilizing SOM, hence maintaining the SOM stock and soil structure in agroecosystems in the longer term.

\section{Earthworm ACtivities and SuCCESSIONal Processes}


Successional processes in vegetation dynamics such as those observed in natural forests may precede or follow significant changes in the organic status of soils. Several examples indicate that earthworm activities during these successions vary significantly (Miles 1985; Scheu 1992) and may be limited to periods when the organic matter that they can digest is available. Sampling soil invertebrate populations in a diachronie series of hevea plantations in the Côte d'Ivoire showed great changes in the soil faunal communities as plantations aged (Gilot et al. 1995).

During the early stages of succession, soil invertebrate communities were dominated by termites, especially xylophagous species. After a few years, the abundance of this group of termites declined, and other groups of termites dominated the termite communities. After 20 years, earthworms became dominant; mesohumic and endogeic species categories prevailed. Finally, in a 30-year plantation, soil invertebrate populations decreased steadily, as did the productivity of the hevea.

It has been suggested that these changes could reflect successions in soil invertebrate communities after changes in the quality and quantity of organic matter. When the plantations were created, woody material from the primary forest was left on the soil surface. Xylophagous termites were the first invertebrate group that used this resource. They transformed decaying wood into fecal pellets that may have been used later by other groups of termites and surface-living earthworms. Eventually, fecal pellets of humivorous termites may have been incorporated into the soil and been used as food by endogeic mesohumic and oligohumic species of earthworms. Once the organic matter from the wood had passed through this food chain and lost most of its energy, which was stored as carbon compounds, the food resource base for soil invertebrates was reduced to the plant residues currently available in the hevea plantation, and invertebrate populations decreased drastically. Interestingly, this sharp decrease in invertebrate populations coincided with a reduction in productivity of the hevea.

These observations suggest that soil invertebrates, especially earthworms, may at some stages use carbon sources that had been previously stored in the soil system at different stages of natural or artificial successional processes. In the case of the hevea plantation, we hypothesize that the activities of soil invertebrates -are sustained, at least partly, by the energy progressively released from decaying logs, resulting in positive effects on hevea productivity.

Our hypothesis that earthworm activities may develop at a determined stage in plant Successions is supported by data from Bernier et al. (1993) in an alpine forest of France located at a 1550-m elevation. In a succession of forest patches from 10 to 190 years old, significant changes in earthworm communities were 
observed (Figure 8.6). In the early stages, earthworm populations were large with a clear dominance of endogeic species populations. Population densities decreased steadily during the subsequent 20 years, and after 60 years, when the forest was mature, earthworm populations started to increase again, although their population density was low. These population changes coincided with clear changes in the amounts and quality of organic matter stored in the humus layers. The proportion of organic matter that was bound to minerals (i.e., organic matter mixed into the soil by earthworm activities) was greatest after 10 years and then decreased steadily, with bound organic matter almost absent after 60 years (Figure 8.7). In the later stages of succession, bound organic matter began to accumulate again. The pattern of changes of unbound organic matter in time was exactly opposite to that of bound organic matter.

The amounts of unbound organic matter decreased when earthworms were abundant and increased when earthworm populations were at low densities. This is evidence that during the cycle of growth, maturation, and senescence of the forest, the humus type changed, with maximum development of a moder after 60 years and a mull after 10 years. We hypothesize that a forest accumulates organic matter as litter and raw humus during its early phases of growth, when primary production is high. Then, earthworm populations start to develop at the expense of these organic accumulations, and they progressively incorporate the nondigested part of this raw organic matter into organomineral complexes (Figure 8.7).

This process results in the release of large quantities of nutrients and the creation of physical soil structures (macroaggregates, macropores, and galleries) typical of a mull-type humus soil. This is believed to be favorable for the establishment and growth of seedlings. Processes by which earthworm populations establish and the reasons why earthworms become able to live in what was previously an acid environment have not yet been identified.

Recent cases of invasion of exotic lumbricid earthworms in northeast United States and Canada provide rather similar situations. There, earthworms are able to feed on organic matter accumulated in these forests, decrease the overall organic matter content, and accelerate the turnover of $\mathrm{C}$ and $\mathrm{N}$, increasing microbial biomass and changing microarthropod communities (see Chapter 5 this volume).

\section{DISCUSSION}


The long-term effects of earthworms on SOM dynamics vary depending on the scale of time considered. When earthworms are introduced artificially into an ecosystem, they use part of the $\mathrm{C}$ resources for their activities. In the African savannahs of Lamto (Côte d'Ivoire), the amount of C mineralized directly through earthworm respiration was estimated as $1.2 \mathrm{t} \mathrm{C} \mathrm{ha}^{-1}$ years in a grass savannah, which is equivalent to about $5 \%$ of overall primary production (Lavelle 1978). The annual average population densities and biomass of earthworms were 202 individuals and $39.7 \mathrm{~g} \mathrm{~m}^{-2}$, respectively, and this population ingested up to 1000 to $1250 \mathrm{t}$ dry soil ha ${ }^{-1}$ year ${ }^{1}$. As part of this process, nutrients were released and made available to plants or microorganisms.

In the same savannah, the overall amounts of assimilable $\mathrm{N}$, released as ammonium in feces, or labile organic $\mathrm{N}$ in dead earthworms and mucus were estimated at 21.1 to $38.6 \mathrm{~kg} \mathrm{ha}^{-1} \mathrm{year}^{-1}$ of NH4-N in a population of Millsonia anomala that comprised $60 \%$ of the overall population biomass. The overall production of mineral $\mathrm{N}$ for the earthworm community is therefore expected to range from 30 to $50 \mathrm{~kg} \mathrm{ha}^{-1}$ year ${ }^{-1}$. In tropical pastures, with earthworrn biomass of 1 to $3 \mathrm{tha}^{-1}$ and soils with higher contents of organic nitrogen, the contribution of earthworms to $\mathrm{N}$ mineralization may probably reach a few hundred kilograms mineral $\mathrm{N}^{-1} \mathrm{y}^{-1}$ year ${ }^{-1}$. In temperate pastures, the flux of mineral $\mathrm{N}$ through earthworms may be estimated as a few hundred kilogram $\mathrm{ha}^{-1}$ year ${ }^{-1}$ (Syers et al. 1979; Harneed et al. 1994). Similar processes have been observed relating to P turnover, but no actual estimates of amounts of P released ha $^{-1}$ year $^{-1}$ have been produced (Sharpley and Syers 1976; LopezHernandez et al. 1993; Brossard et al. 1996). There is some evidence that plants may accumulate these nutrients, but the exact proportion, especially on a yearly basis, is not known (Spain et al. 1992; Hameed et al. 1994).

Increased nutrient turnover from earthworm activities usually results in increased plant growth. Most experiments on the scale of one to six successive cropping cycles showed significant positive effects of earthworm activities on plant productivity; these effects seem to be proportional to the earthworm biomass, within a limited range of biomass (Lavelle 1997). Whether this increased production is sustained in the long term is not known. On one hand, earthworms tend to feed on existing stocks of almost undecomposed organic matter and accelerate their decomposition. Once these stocks are depleted, earthworm activities may cease, and the system returns to lower levels of plant production.

Observations made in rubber plantations of different ages in Côte d'Ivoire seem to support this hypothesis (Gilot et al. 1995). Observations of successional processes in an alpine spruce forest of France showed that earthworm activities seem to have been reduced by an accumulation of low quality litter residues that they could not process rather than by the exhaustion of available organic resources. In that case, spruce litter 
may have become palatable only after long periods of maturation, during which fungal attacks progressively eliminated those toxic compounds present in fresh litter. The effect of litter quality on earthworm activities has already been stressed in studies on Finnish spruce forests, in which the input of high-quality litter allowed earthworm populations to increase significantly even in an acid environment (Huhta 1979).

However, earthworms may participate in the accumulation of organic matter through (1) an overall increase of amounts of organic matter produced in an ecosystem and (2) the protection of SOM in structures of the earthworm drilosphere (burrow system) (Martin 1991). In a 3-year experiment at Yurimaguas and Lamto, the combination of $\mathrm{C}$ consumption by inoculated earthworms, the increased capture of $\mathrm{C}$ by plants, and protection of SOM in compact casts did not result in significant changes in the abundance of C. Nevertheless, there were clear indications that the quality of organic matter, estimated by either physical fractionation or respirometry, was modified. Long term consequences of such modifications are not predictable yet.

Physical effects on soils resulting from earthworm activities seem to persist for long periods; Blanchart et al. (1993) demonstrated that casts deposited by large earthworms (of the compacting category) had largely kept their structures 30 months after the earthworms had disappeared. This resistance of casts, which seems to be because of an outstanding stability of aggregates, seems largely dependent on soil type (Zhang and Schrader 1997). Stabilized earthworm casts tend to conserve organic matter because little microbial activity is possible in these compact structures (McInerney and Bolger 2000; Zhang et al. 2003).

Nevertheless, in natural conditions, such macroaggregates cannot comprise more than 40 to $60 \%$ of the total soil of the Lamto savannah (Blanchart et aL 1993). Despite their continuous production, these aggregates do not accumulate beyond that limit, probably because earthworm populations that decompact soil also regulate the extent of aggregation. These may be the small species earthworms of Eudrilidae at Lamto. They may also be species of Enchytraeidae, ants, termites, myriapoda, or microarthropods. Therefore, the long-term efficiency of these processes of protection of aggregates in earthworm casts depends largely on (1) the maximum percentage of large aggregates present at a given site and (2) the lifetime of these aggregates.

Spatial patterns of earthworm populations may be understood best in terms of their overall impact on soils. At Lamto, there was a significant negative correlation in some seasons among populations of compacting earthworm species that accumulate large compact casts in the upper $20 \mathrm{~cm}$ of soil, decompacting species that produce fine granular-shaped casts from soil macroaggregates, and the large casts produced by the former species (Rossi 1997). This may indicate that earthworm subpopulations have successions inside a patch. 
However, in the Colombian savannah studied by Decaëns and Rossi (2001), the spatial distribution of earthworm populations did not show much change over a 3-year monitoring period, indicating that possible changes in population distribution patterns occur only at rather long sc ales of time. Populations of earthworm species that compact soils can develop once those that decompact soils have produced small aggregates rich in the organic matter that populations of the compacting species may ingest. Such distribution patterns may also be determined by local availability of assimilable organic matter. Studies in both hevea plantations and spruce forests showed clearly that the impacts of earthworms become important when organic matter has been sufficiently prepared by digestion by a succession of termite and arthropods digestions in the first case and the development of fungal colonization in the second.

These results and our hypotheses open several avenues for future research:

1. Testing the effect of earthworm activities on the quality of soil organic matter (through physical fractionations and respirometry) in long-term experiments using natural ${ }^{13} \mathrm{C}$ labeling after, for example, a change from $\mathrm{C} 3$ to $\mathrm{C} 4$ vegetation (Desjardins et al., in press).

2. Establishment of carbon budgets to quantify the amount of $\mathrm{C}$ converted by earthworms and identify the pools in which this $\mathrm{C}$ is taken.

3. Experiments on the effects of the addition of organic matter, in different physical and chemical qualities, on earthworm activities. This last research theme has clear practical implications because what is envisaged is the improvement of earthworm activities in agricultural systems with a view to increase crop production and soil sustainability.

\section{REFERENCES}

Agren, G.I., R.E. McMurtrie, W.J. Parton, J. Pastor, and H.H. Shugart. 1991. State-of-the-art of models of production-decomposition linkages in conifer and grassland ecosystems, Ecol. Appl., 1, 118-138

Aina, P.O. 1984. Contribution of earthworms to porosity and water infiltration in a tropical soil under forest and long-term cultivation, Pedobiologia, 26, 131-136. 
Alegre, J., B. Pashanasi, and P. Lavelle. 1996. Dynamics of soil physical properties in a low input agricultural system inoculated with the earthwonn Pontoscolex corethrurus in Peruvian Amazonia, Soil Sci. Soc. Am. J., 60, 1522- 1529.

Barois, L. and P. Lavelle. 1986. Changes in respiration rate and some physicochemical properties of a tropical soil during transit through Pontoscolex corethrurus (Glossoscolecidae, Oligochaeta), Soil Biol. Biochem., 18, 539-541.

Barois, I., P. Lavelle, M. Brossard, J. Tondoh, M.A. Martinez, J.P. Rossi, B.K. Senapati, A. Angeles, C. Fragoso, J.J. Jimenez, T. Decaëns, C. Lattaud, K.K. Kanyonyo, E. Blanchart, L. Chapuis, G.G. Brown, and A. Moreno. 1999. Ecology of earthworm species with large environmental tolerance and/or extended distributions, in Earthworm Management in Tropical Agroecosystems, P. Lavelle, L. Brussaard, and P. Hendrix, Eds., CAB International, Wallingford, U.K., pp. 57-86.

Bernier, N., J.F. Ponge, and J. André. 1993. Comparative study of soil organic layers in two bilberry spruce forest stands (Vaccinio-Picetea). Relation to forest dynamics, Geoderma, 59, 89-108.

Blair, J.M., R.W. Parmelee, and P. Lavelle. 1994. Influence of earthworms on biogeochemistry in North American ecosystems, in Earthworm Ecology in Forest Rangeland and Crop Ecosystems in North America, P.F. Hendrix, Ed., Lewis Publishers, Chelsea, MI, pp. 1-44.

Blanchart, E., A. Albrecht, J. Alegre, A. Duboisset, B. Pashanasi, P. Lavelle, and L. Brussaard. 1999. Effects of earthworms on soil structure and physical properties, in Earthworm Management in Tropical Agroecosystems, P. Lavelle, L. Brussaard, and P. Hendrix, Eds., CAB International, Wallingford, U.K., pp. 139-162.

Blanchart, E., A. Bruand, and P. Lavelle. 1993. The physical structure of casts of Millsonia anomala (Oligochaeta: Megascolecidae) in shrub savannah soils (Côte d'Ivoire), Geoderma, 56, 119- 132.

Bonkowski, M., B.S. Griffiths, and K. Ritz. 2000. Food preferences of earthworms for soil fungi, Pedobiologia, 44, 666-676.

Bouché, M.B. 1977. Stratégies lombriciennes, in Soil Organism as Components of Ecosystems, T. Persson and U. Lohm, Eds., Ecol. Bull. (Stockholm), 25, 122-132. 
Brossard, M., P. LaveIle, and J.Y. Laurent. 1996. Digestion of a vertisol by an endogeic earthworm (Polypheretima elongata, Megascolecidae) increases soil phosphate extractibility, Eur. J. Soil Biol., 32, 107-111.

Chauvel, A., M. Grimaldi, E. Barros, E. Blanchart, T. Desjardins, M. Sarrazin, and P. Lavelle. 1999. Pasture degradation by an Amazonian earthworm, Nature, 389, 32- 33.

Darwin, C. 1881. The Formation of Vegetable Mould Through the Action of Worms, with Observations of Their Habits, Murray, London.

Decaëns, T., J.H. Galvin, and E. Amezquita, E. 2001. Propriétés des structures produites par les ingénieurs écologiques à la surface du sol d'une savane colombienne, C.R. Acad. Sci. Life Sci., 324, 465-478.

Decaëns, T., P. Lavelle, J.J. Jimenez Jaen, G. Escobar, and G. Rippstein. 1994. Impact of land management on soil macrofauna in the Oriental Llanos of Colombia, Eur. J. Soil Biol., 30, 157-168.

Decaëns, T. and J. Rossi. 2001. Spatial and temporal structure of earthworm community and soil heterogeneity in a tropical pasture, Ecography, 24, 671-682.

Derouard, L., J. Tondoh, Vilcosqui, and P. Lavelle. 1997. Species-specific effects in the response of tropical annual crops to the inoculation of earthworms. Short-scale experiments at Lamto (Côte d'Ivoire), Soil Biol. Biochem., 29(3-4), 541-545.

Desjardins, T., F. Charpentier, B. Pashanasi, A. Pando-Bahon, P. Lavelle, and A. Mariotti. (in press). Effects of earthworm inoculation on soil organic matter dynamics of a cultivated ultisol, Pedobiologia.

Devliegher, W. and W. Verstraete. 1997. Microorganisms and soil physico-chemical conditions in the drilosphere of Lumbricus terrestris, Soil Biol. Biochem., 29,1721-1729.

Didden, W.A.M. 1990. Involvement of Enchytraeidae (Oligochaeta) in soil structure evolution in agricultural fields, Biol. Fertil. Soils, 9,152-158.

Edwards, C.A. and P.J. Bohlen. 1996. Biology and Ecology of Earthworms, Chapman \& Hall, London.

Elliott, E.T. 1986. Aggregate structure and carbon, nitrogen, and phosphorus in native and cultivated soils, Soil Sci. Soc. Am. J., 50, 627-633. 
Eswaran, F. 1994. Soil resilience and sustainable land management in the context of AGENDA 21, in Soil Resilience and Sustainable Land Use, D.J. Greenland and I. Szabolcs, Eds., CAB International, Wallingford, U.K.

FAO. 2000. La situation mondiale de l'alimentation et de l'agriculture. FAO (Rome), vol. 32,497 pp.

Feller, C. 1979. Une méthode de fractionnement granulométrique de la matière organique des sols: application aux sols tropicaux à texture grossière, très pauvres en humus, Cahiers de l'O.R.S.T.O.M., Sér. Pédol.; 17(4), 339-346.

Ferrière, G. 1980. Fonctions des Lombriciens.VII. Une méthode d'analyse de la matière organique végétale ingérée, Pedobiologia, 20, 263-273,

Gilot, C. 1997. Effects of a tropical geophageous earthworm, M-anomala (Megascolecidae), on soil characteristics and production of a yam crop in Ivory Coast, Soil Biol. Biochem., 29, 353-359.

Gilot, C., P. Lavelle, Ph. Kouassi, and G. Guillaume. 1995. Biological activity of soils in Hevea stands of different ages in Côte d'Ivoire, Acta Zool. Fenn., 196, 186-190.

Hameed, R., M.B. Bouché, and J. Cortez. 1994. Etudes in situ des transferts d'azote d'origine lombricienne (Lumbricus terrestris L.) vers les plantes, Soil Biol. Biochem., 26, 495-501.

Huhta, V. 1979. Effects of liming and deciduous litter on earthworm (Lumbricidae) populations of a spruce forest, with an inoculation experiment on Allolobophora caliginosa, Pedobiologia, 19, 340-345.

Jenkinson, D.S. and J.H. Rayner. 1977. The turnover of soil organic matter in some of the Rothamsted c1assical experiments, Soil Sci., 123, 298-305.

Jimenez, J.J., J.P. Rossi, and P. Lavelle. 2001. Spatial distribution of earthworms in acid-soil savannas of the Eastern plains of Colombia, Appl. Soil Ecol., 17(3), 514.

Joschko, M., H. Diestel, and O. Larink. 1989. Assessment of earthworm burrowing efficiency in compacted soil with a combination of morphological and soil physical measurements, Biol. Fertil. Soils, 8, 191-196.

Kanyonyo ka Kajondo, J.B. 1984. Ecologie alimentaire du ver de terre detritivore Millsatia lamtoiarta (Acanthdrilidae, Oligochètes) dans la savane de Lamto (Côte d'Ivoire), Ms.C. thesis, Paris VI. 
Kladivko, E.J., A.D. Mackay, and J.M. Bradford. 1986. Earthworms as a factor in the reduction of soil crusting, Soil Sci. Soc. Am. J., 50, 191-196.

Kooistra, M.J. 1991. A micromorphological approach to the interactions between soil structure and soil biota, Agric. Ecosyst. Environ., 34, 315-328.

Lavelle, P. 1978. Les Vers de Terre de la Savane de Lamto (Côte d'Ivoire): Peuplements, Populations, et Fonctions dans l'Écosystème, Publications du Laboratoire de Zoologie de l'ENS no. 12, Paris.

Lavelle, P. 1997. Faunal activities and soil processes: adaptive strategies that determine ecosystem function, $A d v$. Ecol. Res., 27, 93-132.

Lavelle, P., D. Bignell, M. Austen, Y. Brown, V. Behan-Pelletier, J. Garey, P. Giller, S. Hawkins, G. Brown, M. St. John, B. Hunt, and E. Paul. 2004. Vulnerability of ecosystem services at different scales: role of biodiversity and implications for management, in Sustaining Biodiversity and Functioning in Soils and Sediments, D. H. Wall, Ed., Island Press, New York, in press.

Lavelle, P., E. Blanchart, A. Martin, S. Martin, I. Barois, F. Toutain, A. Spain, and R. Schaefer, 1993. A hierarchical model for decomposition in terrestrial ecosystems. Application to soils in the humid tropics, Biotropica, 25, 130-150.

Lavelle, P., L. Brussaard, and P. Hendrix. 1999. Earthworm Management in Tropical Agroecosystems, CAB International, Wallingford, U.K.

Lavelle, P., M. Dangerfield, C. Fragoso, V. Eschenbrenner, D. Lopez-Hernandez, B. Pashanasi, and L. Brussaard. 1994. The relationship between soil macrofauna and tropical soil fertility, in The Biological Management of Tropical Soil, M.J. Swift and P. Woomer, Eds., John Wiley-Sayce, New York, pp. 137169.

Lavelle, P. and A. Martin. 1992. Small-scale and large-scale effects, of endogeic earthworms on soil organic matter dynamics in soils of the humid tropics, Soil Biol. Biochem. , 24, 1491-1498.

Lavelle, P., G. Melendez, B. Pashanasi, and R Schaefer. 1992. Nitrogen mineralization and reorganisation in casts of the geophagous tropical earthworm Pontoscolex corethrurus (Glossoscolecidae), Biol. Fertil. Soils, 14, 49-53. 
Lavelle, P. and A.V. Spain. 2001. Soil Ecology, Kluwer Scientific, Amsterdam.

Lee, K.E. 1985. Earthworms: Their Ecology and Relationships with Soils and Land Use, Academic Press, New York.

Lopez-Hernandez, D., J.C. Fardeau, and P. Lavelle. 1993. Phosphorus transformations in two P-sorption contrasting tropical soils during transit through Pontoscolex corethrurus (Glossoscolecidae, Oligochaeta), Soil Biol. Biochem., 25, 789-792.

Mariani, L., N. Bernier, J.J. Jimenez, and T. Decaëns. 2001. Diet of an anecic earthworm from the Colombian savannas: a question about ecological categories, C.R Acad. Sci. Sér. 3, 733-742.

Martin, A. 1991. Short- and long-term effects of the endogeic earthworm Millsonia anomala (Omodeo) (Megascolecidae, Oligochaeta) of tropical savannas on soil organic matter, Biol. Fertil. Soils , 11, 234238.

McInerney, M. and T. Boiger. 2000. Decomposition of Quercus petraea litter: influence of burial, comminution and earthworms, Soil Biol. Biochem., 32, 1989-2000.

McLean, M.A. and D. Parkinson. 1997. Soil impacts of the epigeic earthworm Dendrobaena octaedra on organic matter and microbial activity in lodgepole pine forest, Can. J. Forest Res., 27, 1907-1913.

McLean, M.A. and D. Parkinson. 2000. Field evidence of the effects of the epigeic earthworm Dendrobaena octaedra the microfungal community in pine forest floor, Soil Biol. Biochem., 32, 351-360.

Miles, J. 1985. Soil in the ecosystem, in Ecological Interactions in Soil: Plants, Microbes and Animals, D. Atkinson, A.H. Fitter, D.J. Read, and M.B. Usher, Eds., Blackwell Scientific, Oxford, U.K., pp. 407427.

Molina, J.A.E., C.E. Clapp, M.J. Shaffer, F.W. Chichester, and W.E. Larson. 1983. NCSOIL, a model of C and $\mathrm{N}$ transformations in soils: description, calibration and behaviour, Soil Sci. Soc. Am. J., 47,85-91.

Neilson, R, B. Boag, and M. Smith. 2000. Earthworm delta C-13 and delta N-15 analyses suggest that putative functional classifications of earthworms are site-specific and may also indicate habitat diversity, Soil Biol. Biochem., 32, 1053-1061. 
Oades, J.M. 1984. Soil organic matter and structural stability: mechanisms and implication for management, Plant Soil, 76, 319-337.

Parton, W.J., J.W.B. Stewart, and C.V. Cole. 1988. Dynamics of C, N, P and S in grasslands soils: a model, Biogeochemistry, 5, 109-131.

Pashanasi, B., P. Lavelle, and J. Alegre. 1996. Effect of inoculation with the endogeic earthworm Pontocolex corethrurus on soil chemical characteristics and plant growth in a low-input agricultural system of Peruvian Amazonia, Soil Biol. Biochem., 28, 801-810.

Phillipson, J., R Abel, J. Steel, and S.R. Woodell. 1976. Earthworms and the factors that govern their distribution, Oecologia, 33, 291-309.

Piearce, T.G. 1978. Gut contents of some lumbricid earthworms, Pedobiologia, 18, 3-157.

Poier, K.R and J. Richter. 1992. Spatial distribution of earthworms and soil properties in an arable loess soil, Soil Biol. Biochem. , 24, 1601-1608.

Rossi, J.P. 1997. Rôle fonctionnel de la distribution spatiale des vers de terre dans une savane humide de Côte d'Ivoire. Doctoral thesis, University of Paris VI, Paris.

Rossi, J.P., P. Lavelle, and A. Albrecht. 1997. Relationships between spatial pattern of the endogeic earthworm Polypheretima elohgata and soil heterogeneity in a tropical pasture of Martinique (French West Indies), Soil Biol. Biochem., 29(3-4), 481-485.

Satchell, J.E. 1983. Earthworm Ecology from Darwin to Vermiculture, Chapman \& Hall, London, 495 pp.

Scheu, S. 1992. Changes in the lumbricid coenosis during secondary succession from a wheat field to a beechwood on limestone, Soil Biol. Biochem., 24, 1641-1646.

Scullion, J. and A. Malik. 2000. Earthworm activity affecting organic matter, aggregation and microbial activity in soils restored after opencast mining for coal, Soil Biol. Biochem., 32, 119-126.

Sharpley, AN. and J.K. Syers. 1976. Potential role of earthworm casts for the phosphorus enrichment of runoff waters, Soil Biol. Biochem., 8, 341-346. 
Shaw, C. and S. Pawluk. 1986. The development of soil structure by Octolasion tyrtaeum, Aporrectoded turgida and Lumbricus terrestris in parent materials belonging to different textural classes, Pedobiologia, 29, 327-339.

Shuster, W.D., S. Subler, and E.L. McCoy. 2001. Deep-burrowing earthworm additions changed the distribution of soil organic carbon in a chisel-tilled soil, Soil Biol. Biochem., 33, 983-996.

Spain, AV., P Lavelle, and A. Mariotti. 1992. Stimulation of plant growth by tropical earthworms, Soil Biol. Biochem., 24, 1629-1634.

Springett, J.A 1983. Effect of five species of earthworm on some soil properties, J. Appl. Ecol., 20, 865-887.

Syers, J.K., AN. Sharpley, and D.R. Keeney. 1979. Cycling of nitrogen by surface-casting earthworms in a pasture ecosystem, Soil Biol. Biochem., 11, 181-185.

Tajovsky, K., G. Villemin, and P. Toutain. 1991. Microstructural and ultrastructural changes of the oak litter consumed by millipede Glomeris hexasticha (Diplopoda), Rev. d'Ecol. Biol. du Sol, 28, 287- 302.

Tiunov, AV., M. Bonkowski, J. Alphei, and S. Scheu. 2001. Microflora, Protozoa and Nematoda in Lumbricus terrestris burrow walls: a laboratory experiment, Pedobiologia, 45, 46-60.

Tsakala, R. 1994. Evolution Spatio-Temporelle de la Minéralisation du Carbne et de l'Azote dans les Sols de Deux Parcelles à Lamto (Côte d'Ivoire), Mémoire DESS, Université Paris 12.

Van Vliet, P.C.J., L.T. West, P.P. Hendrix, and D.C. Coleman. 1993. The influence of Enchytraeidae (Oligogochaeta) on the soil porosity of small microcosms, Geoderma, 56, 287-299.

Wolters, V. 1991. Soil invertebrates - effects on nutrient turnover and soil structure - a review, Z. Pflanzenernahr. Bodenk., 154, 389-402.

Zhang, B.G., G.T. Li, T.S. Shen, J.K. Wang, and Z. Sun. 2000. Changes in microbial biomass C, N, and P and enzyme activities in soil incubated with the earthworms Metaphire guillelmi or Eisenia fetida, Soil Biol. Biochem., 32, 2055-2062.

Zhang, X., J. Ang, H. Xie, J. Wang, and W. Zech. 2003. Comparison of organic compounds in the particle-size fractions of earthworm casts and surrounding soil in humid Laos, Appl. Soil Ecol., 23, 147- 153. 
Zund, P.R., U. Pillai McGarry, D. McGarry, and S.G. Bray. 1997. Repair of a compacted oxisol by the earthworm Pontoscolex corethrurus (Glossoscolecidae, Oligochaeta), Biol. Fertil. Soils, 25, 202-208. 


\section{LEGENDS OF FIGURES}

FIGURE 8.1 Relationships of earthworms and other soil "ecosystem engineers" with other soil biological components. Earthworms partly influence the occurrence and activity of other soil organisms because they create large structures that may persist over significant periods and affect the environment. (From Lavelle 1997. With permission.)

FIGURE 8.2 Effects of earthworm activities on soil processes operating at different scales.

FIGURE 8.3 Effects of earthworm activities on SOM dynamics at different scales of time and space.

FIGURE 8.4 Changes in carbon and nitrogen contents in an ultisol of Peruvian Amazonia submitted to traditional slash-and-burn agriculture in the presence and absence of earthworrns (Pontoscolex corethrurus). Pairs of data with different letters are significantly different. (From Pashanasi et al. 1996. With permission.)

FIGURE 8.5 Changes of carbon contents in soils of a grass savanna at Lamto (Côte d'Ivoire) in the presence and absence of endogeic earthworms; results of a simulation using the CENTURY model. (From A. Martin and W.J. Parton unpublished data, 1993.)

FIGURE 8.6 Changes in the abundance of earthworms of different ecological categories along a succession in an alpine spruce forest. (From Bernier et al. 1993. With permission.) 
FIGURE 8.7 Changes in the abundance of organic matter (OM) bounded to soil minerals and unbounded organic matter along a succession in an alpine spruce forest. (From Bernier et al. 1993. With permission.) 


\section{TABLE 8.1}

Effects of Inoculation of the Earthworm Millsonia anomala into Cropping Systems on Bulk Density and Aggregation of Soil

\begin{tabular}{|c|c|c|c|c|c|}
\hline & \multicolumn{2}{|c|}{ Bulk Density } & \multicolumn{3}{|c|}{$\%$ Aggregates larger than $2 \mathrm{~mm}$} \\
\hline & $\begin{array}{c}\text { Maize } \\
0-10 \mathrm{~cm}\end{array}$ & $\begin{array}{c}\text { Maize } \\
0-10 \mathrm{~cm}\end{array}$ & $\begin{array}{l}\text { Yam Mounds, } \\
\text { Sieved Soil }\end{array}$ & $\begin{array}{l}\text { Maize 0-10 cm, } \\
\text { Undisturbed Soil }\end{array}$ & $\begin{array}{l}\text { Maize 0-10 cm, } \\
\text { Sieved Soil }\end{array}$ \\
\hline Time (months) & 3 & 36 & 34 & 36 & 36 \\
\hline Inoculated & 1.31 & 1.48 & 53.5 & 42.5 & 42.2 \\
\hline Noninoculated & 1.24 & 1.37 & 29.8 & 38.8 & 24.6 \\
\hline$p$ & 0.06 & $<0.001$ & $<0.05$ & n.s. & $<0.01$ \\
\hline
\end{tabular}

n.s., not significant 
Interactions

with microflora for digestion

of complex organic molecules

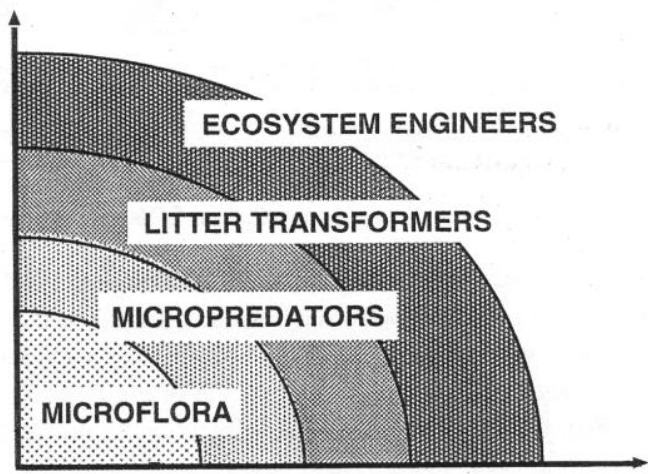

Formation of biogenic structures

Fig. 8.1 


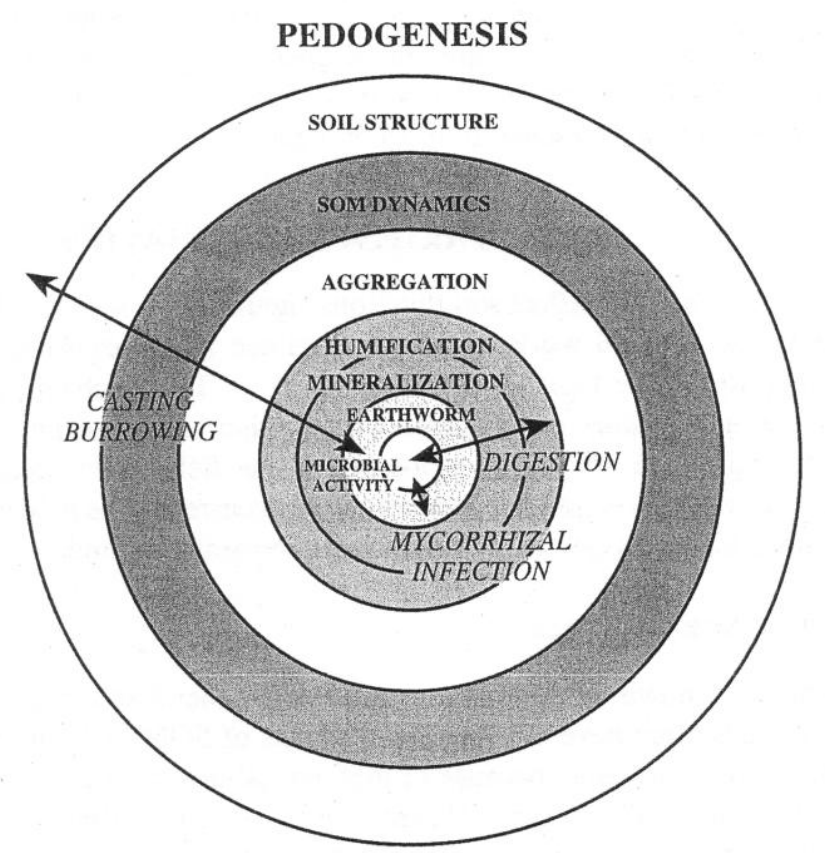

Fig. 8.2 
Functional Groups

Spatial Distribution

\begin{tabular}{|c|c|c|c|c|}
\hline $\begin{array}{l}\text { Time } \\
\text { Structure }\end{array}$ & $\begin{array}{l}\text { HOURS } \\
\text { GUT CONTENT }\end{array}$ & $\begin{array}{l}\text { DAYS/WEEKS } \\
\text { FRESH CASTS }\end{array}$ & $\begin{array}{c}\text { MONTHS } \\
\text { AGING CASTS }\end{array}$ & $\begin{array}{l}\text { YEARS: DECADES } \\
\text { SOIL PROFILE }\end{array}$ \\
\hline & & & जि: & 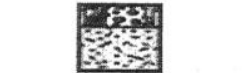 \\
\hline $\begin{array}{l}\text { Effect on } \\
\text { SOM }\end{array}$ & $\begin{array}{l}\text { ASSIMILATION } \\
\text { COMMINUTION }\end{array}$ & $\begin{array}{l}\text { NUTRIENT } \\
\text { RELEASE }\end{array}$ & $\begin{array}{l}\text { PHYSICAL } \\
\text { PROTECTION }\end{array}$ & $\begin{array}{l}\text { ACCELERATION } \\
\text { OF TURNOVER }\end{array}$ \\
\hline
\end{tabular}

Fig. 8.3 

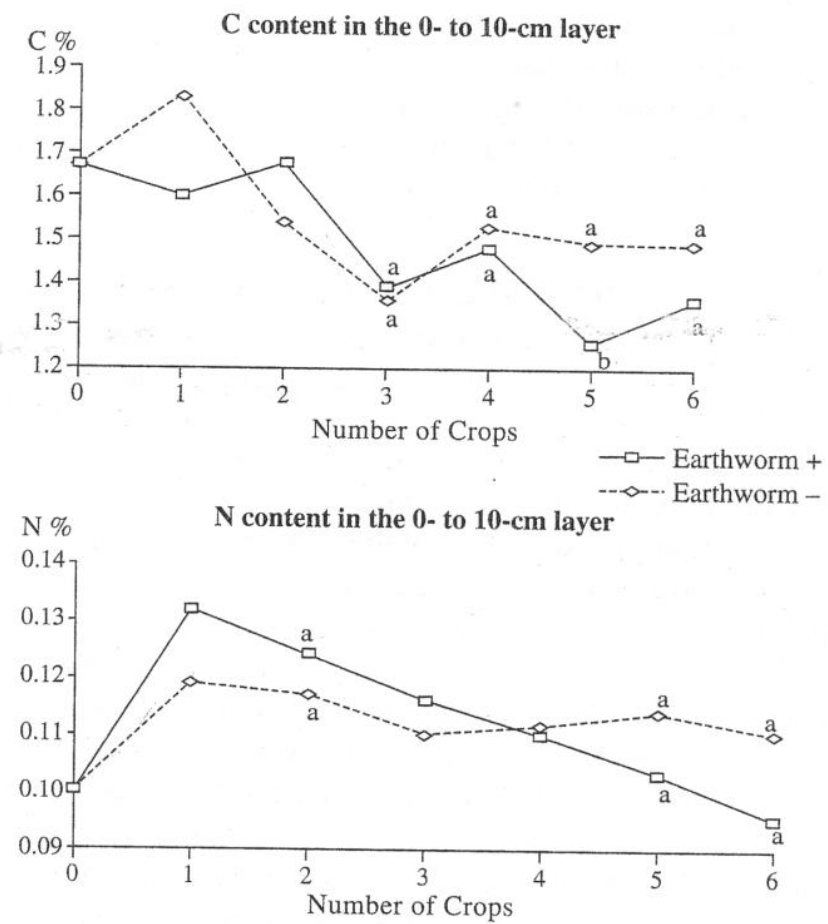

Fig. 8.4 


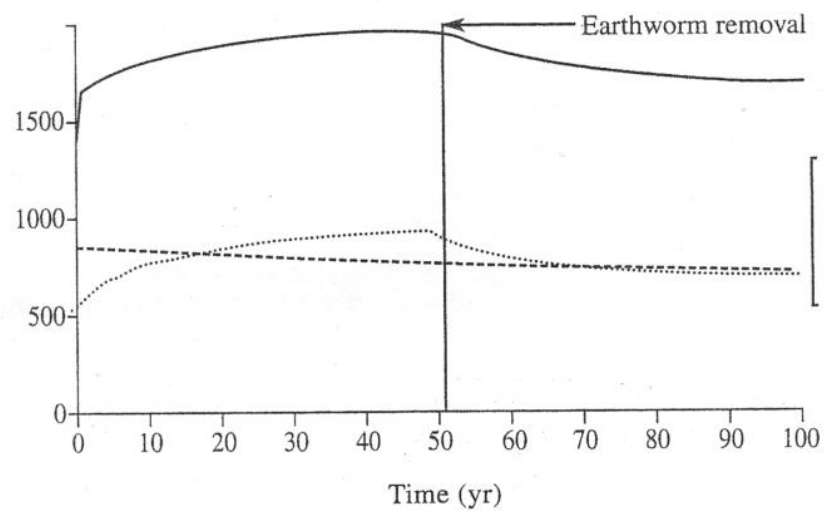

Fig. 8.5 


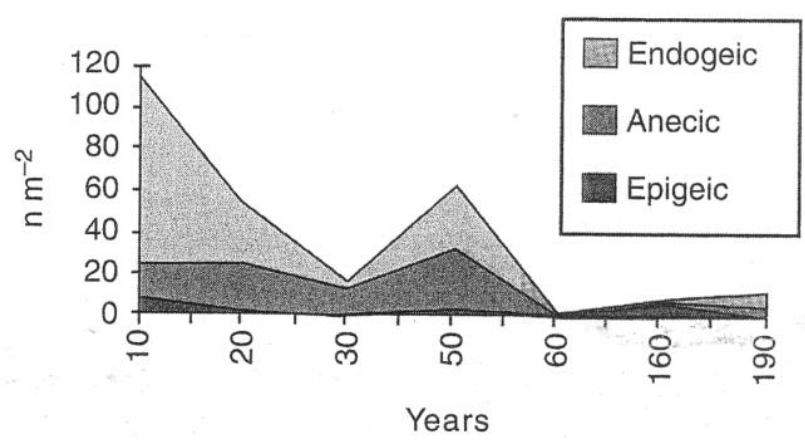

Fig. 8.6 
$\% \min$

materials

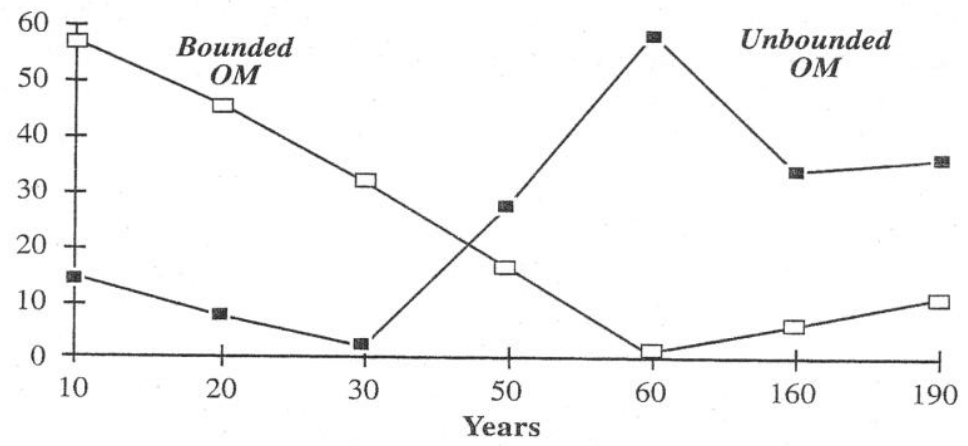

Fig. 8.7 